\title{
Gastric heterotopia in the gallbladder: Mimicking the tumor imagine in radiology
}

\section{Safra kesesinde radyolojik olarak tümörü taklit eden heterotopik mide olgusu}

\author{
Neşe Yeldirr ${ }^{1}$, Nisa Başpınar², Hatice Özer ${ }^{1}$, Ömer Topçu ${ }^{3}$
}

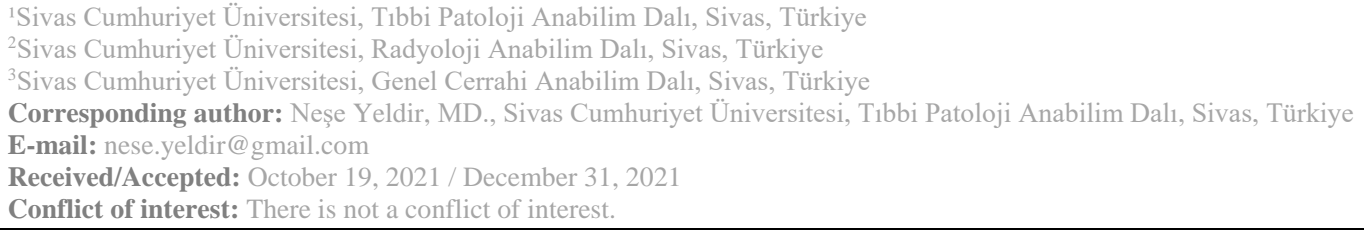

\section{SUMMARY}

Heterotopia is mass of tissue normal to the site in abnormal location. Heterotopic gastric mucosa has been described in almost every part of the gastrointestinal tract including the tongue, oesophagus, epiglottis, small bowel, appendix vermiformis, rectum and gallbladder. The diagnosis of heterotopic gastric mucosa in gallbladder can be difficult clinically . Heterotopic gastric mucosa in gallbladder can be symptomatic or detected incidentally. It is relevant to distinguish heterotopic gastric mucosa from benign polyps, gallbladder carcinoma or metastasis. We present a case of a 51 year old female patient who represented suspicious lesion on computed tomography (CT). After cholecystectomy, in the microscopical examination gastric mucosa consisting of fundic glands and pyloric glands and typical features of chronic cholecystitis are seen.

Keywords: Gallbladder, heterotopic gastric mucosa, chronic cholecystitis
(iD) Neşe Yeldir
(iD) Nisa Başpınar
(iD) Hatice Özer
(D) Ömer Topçu

\section{ÖZET}

Heterotopi normal dokuların oluşturduğu anormal yerleşimli kitledir. Heterotopik mide mukozası dil, özefagus, epiglot, ince barsak, apendiks vermiformis, rektum ve safra kesesi olmak üzere gastrointestinal sistemin her bölgesinde tariflenmiștir. Safra kesesinde heterotopik mide mukozasını klinik olarak tanımak zordur. Heterotopik mide mukozası semptomatik olabilir ya da insidental olarak saptanır. Heterotopik mide mukozası, benign polipler, safra kesesi karsinomu ve metastazlar ile karışabilir. Bilgisayarlı tomografide (BT) safra kesesinde şüpheli lezyon bulunan 51 yaşında bir kadın hasta olgusunu sunduk. Kolosistektomi sonrası, mikroskobik incelemede mide mukozası fundik ve pilorik glandları içermekte olup safra kesesinde kronik kolesistitin tipik özellikleri görülmektedir.

N.Y. 0000-0002-3812-6245

N.B. $0000-0003-4240-6001$

H.Ö. 0000-0001-6479-3626

Ö.T. 0000-0002-1017-9820 


\section{INTRODUCTION}

Heterotopia is describeted as physiological tissue in an aberrant localization ${ }^{1}$. Heterotopic gastric mucosa has been reported many location of the gastrointestinal tract. It is usually located in the upper intestine and extremely rare in the gallbladder $^{2}$. In the literature, heterotopic gastric mucosa, intestine mucosa, pacreas and liver tissue are been reported in the gallbladder ${ }^{3}$. Most of the these cases were represented polypoid lesion or thickening on the wall since was reported firstly in $1934^{4}$. It was presented also as cystic mass ${ }^{5}$. It is recommended that if there is suspicious mass on the wall, cholecystectomy must be performed ${ }^{6}$.

\section{CASE REPORT}

A 51- year- old female patient admitted to the clinic with abdominal pain. No pathological finding was found in laboratory values.

Ultrasonography (US) revealed a broad-based polypoid lesion $1,2 \mathrm{~cm}$ in diameter in the body of the gallbladder with two of gallstones. The polypoid lesion is also seen at $\mathrm{CT}$ and the lesion density was 50 Hounsfield Unit which is soft tissue density.

The surgical specimen included a 10x6x5 mm polypoid lesion in the corpus of gallbladder.

Histologically, the polypoid lesion consisted of gastric mucosa composed of fundic and pyloric glands. Other gallbladder mucosa demonstrated pyloric metaplasia and chronic cholecystitis findings.
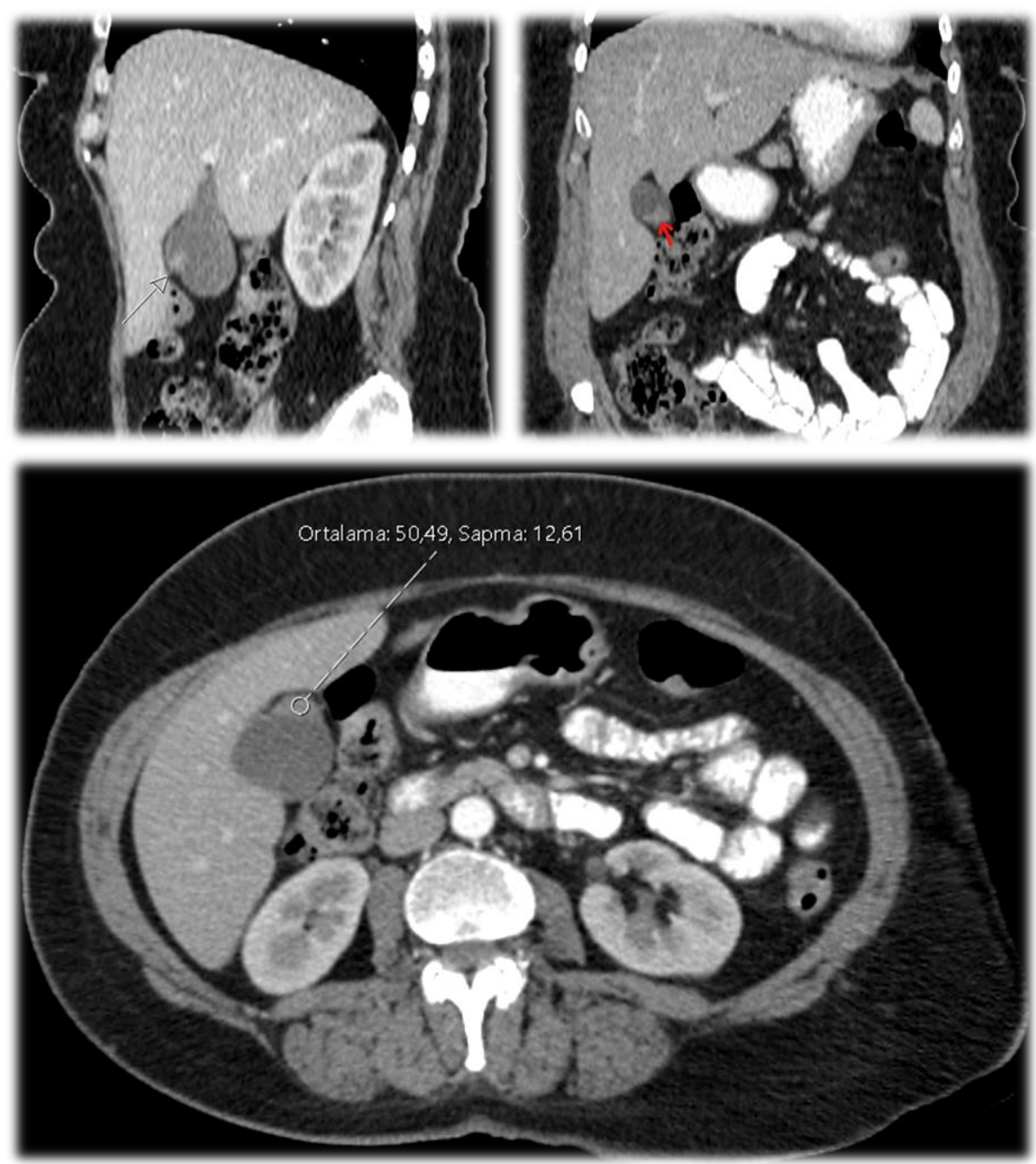

Figure 1(a)(b)(c): Images of the case on CT. 

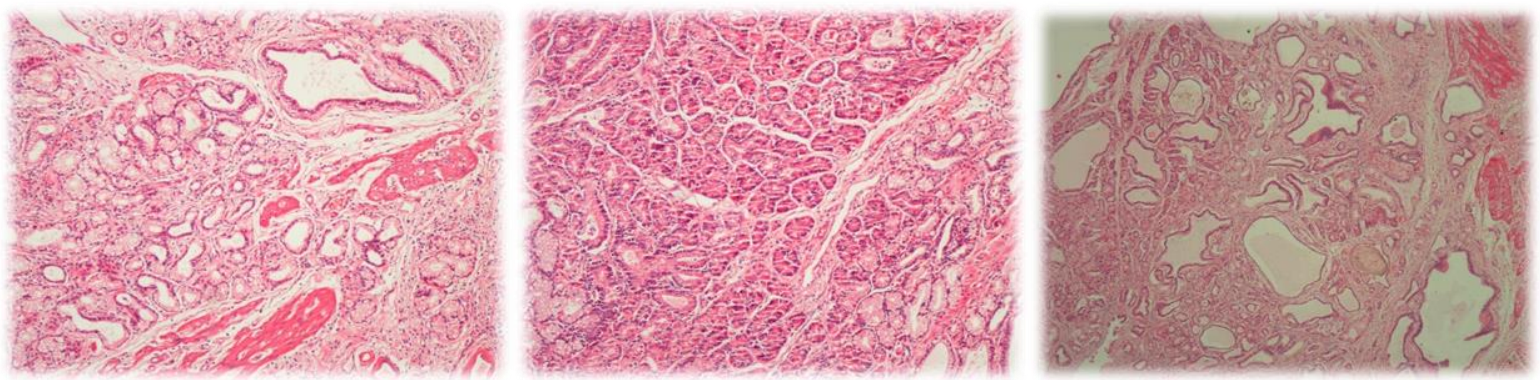

Figure 2(a)(b)(c): Histological appearance of heterotopic gastric mucosa in the gallbladder

(H\&E,x40).

\section{DISCUSSION}

Heterotopic tissue of various types in the gallbladder has been reported in the literature, including gastric mucosa, pancreatic tissue, liver tissue, and others such as adrenal and thyroid tissue $^{7}$. Heterotopic gastric mucosa is described almost every location in the gastrointestinal tract, from the oral cavity to the rectum ${ }^{8-9}$. The first case of heterotopic gastric mucosa in the gallbladder was reported in $1934^{10}$. It is a rare entity which concerns all ages and is presenting with abdominal discomfort with cholecystitis like pain or asymptomatically.

There are three hypotheses regarding the etiology of heterotopic gastric mucosa: ${ }^{1}$ developmental anomaly, ${ }^{2}$ heterotopic differentiation and ${ }^{3}$ metaplastic differentiation ${ }^{11}$.

The diagnosis of heterotopic gastric mucosa in gallbladder can be difficult clinically. The differential diagnosis comprises various disorders if a polypoid lesion is detected. It is relevant to distinguish heterotopic gastric mucosa from benign polyps, gallbladder carcinoma or metastasis. Important differential diagnoses are malignant neoplasms, especially gallbladder carcinoma, because of different treatment regime ${ }^{1}$.

On microscopic examination, the characteristic feature of this lesion is the presence of fundic glands with parietal and chief cells and pyloric type mucous glands. Pyloric gland and intestinal metaplasia in the gallbladder is most common in cholecystectomy specimens. Gastric metaplasia in gallbladder is composed of only pyloric glands. Heterotopic gastric mucosa can be together with metaplastic or dysplastic areas ${ }^{12}$.

In conclusion, the heterotopic tissues can be confused clinically with neoplasms. Malignant neoplasms of gallbladder are important differential diagnosis on suspicious masses. They can be symptomatic or detected incidentally. Although imaging features can be helpful to distinguish between heteretopic gastric mucosa and gallbladder carcinoma the final diagnosis is made by histopathology after cholecystectomy.

\section{REFERENCES}

1. Beeskow A B, Meyer H J, Schierle K, Surov A. Heterotopic gastric mucosa in gallbladder: a rare differential diagnosis to gallbladder masses. Medicine 2018;97:10.

2. Vallera D U, Dawson P J, Path F R C. Gastric heterotopia in the gallbladder case report and review of literature. Pathol Res Pract 1992 Feb;188(1-2):49-52.

3. Pradines $\mathrm{P}$, Brauner M, Legrand I. Heterotopic gastric mucosa in the gallbladder. AJR 1989;152:432.

4. Egyedi L. Case of polyps of the gallbladder containing an aberrant gastric mucous membrane. Gyogyaszat 1934;74:596-9.

5. Yiğit $\mathrm{T}$, Güleç $\mathrm{B}$, Yiğitler $\mathrm{C}$, Balkan $\mathrm{M}$, Eryılmaz M, Öner K. Cystic mass with heterotopic gastric mucosa next to gallbladder: A case report. Akademik Gastroentererol Derg 2004;3(3):147-149.

6. Sözen S, Emir S, Özdemir C Ş. Heterotopic liver tissue on the gallbladder wall:a case report heterotopic liver tissue. Med J Kocaeli 2012;3:42-45.

7. Madrid C, Berrocal T, Gorospe L, Prieto C, Gamez M. Heterotopic gastric mucosa involving the gallbladder and biliary tree. Pediatr Radiol 2003;33:129-32.

8. Popkharitov A I, Gulubova M V, Dandov A D, Sivrev D P. Heterotopic gastrointestinal cyst mimicking chronic cholecystitis:a case report. J Med Case Rep 2008;2:173.

9. Ozden H, Gömeç M, Kurtulan O. Ectopic Pancreas Tissue in the Gallbladder: An 
Incidental Mass in Laparoscopy. Arch Iran Med 2020;23(11):761:763.

10. Egyedi L. Case of polyps of gallbladder containning aberrant gastric mucous membrane (in Hungarian). Gyogyaszat (Gyogyastat) 1934;74:596-9.

11. Hamazaki K, Fujıwara T. Heterotopic gastric mucosa in the gallbladder. J Gastroenterol 2000; 35:376-381.
12. Xeropotamos N, Skopelitou A S, Batsis C, Kappas A M. Heterotopic gastric mucosa together with intestinal metaplasia and moderate dysplasia in the gallbladder: report of two clinically unusual cases with literature review. Gut 2001;48:719-723. 